PRIFYSGOL

glyndîn

Glyndŵr University

Glyndŵr University Research Online

Theology

Theology

$1-1-1992$

\title{
Three Generations on: The Methodology of Pentecostal History
}

William K. Kay

GlyndwrUniversity, w.kay@glyndwr.ac.uk

Follow this and additional works at: http://epubs.glyndwr.ac.uk/theo

Part of the Religious Thought, Theology and Philosophy of Religion Commons

This article was published in the EPTA Bulletin 1992, the Journal of the European Pentecostal Theological Association. The journal website is at http://www.eptaonline.com/

\section{Recommended Citation}

Kay, W. K. (1992) 'Three Generations on: The Methodology of Pentecostal History'. EPTA Bulletin, XI (1+2), 58-70.

This Article is brought to you for free and open access by the Theology at Glyndŵr University Research Online. It has been accepted for inclusion in Theology by an authorized administrator of Glyndŵr University Research Online. For more information, please contact d.jepson@glyndwr.ac.uk. 
EPTA BULLETIN Journal of the European Pentecostal Theological Association, Vol. XI, No.1+2,, 1992, pp58-70.

\section{Three Generations on: The Methodology of Pentecostal History}

[This paper was first presented at the Twentieth Annual Meeting of the Society for Pentecostal Studies at Dallas Texas, in 1990]

by William K. Kay

I propose to discuss in this paper some of the problems which arise in the writing of Pentecostal history and, in doing so, to relate these to church history generally and to secular history. In addition I also intend to suggest methodological solutions to these problems, though I cannot pretend to have solved all the difficulties which arise and, in some cases, I have done no more than point to most intense areas of most intense intractability.

\section{THE PROBLEMS}

\section{Providence}

The first problem, and the one to which I wish to devote most attention, concerns the identification of providential events, that is, events more or less directly caused by God in the natural world for the benefit of human beings. Pentecostal history is full of accounts of miraculous events of various kinds: some of these concern simple answers to prayer, others refer to dramatic miracles of healing or guidance or conversion and, woven with these into the general tapestry of Pentecostalism is the recurrent attestation of glossolalia which, by its nature, is an interactive process which is both natural and supernatural, and therefore providential.

If we treat such events as non-providential and do our best to find explanations for them which neither invoke God nor require anything beyond a naturalistic world view, then we run the risk of reinterpreting Pentecostal history beyond the recognition of those who participated in it. To take an illustrative case: if we wrote a history of the Reformation entirely in Marxist terms, we would have to assume that the major causes of the changes in the church and in Europe in the 16th century were initiated by the rebellion of the proletariat, the iron laws of history, dialectical materialism, and so forth and we would leave out of the explanation the rediscovery of the truth of justification by faith and the consequences for the church of this truth. If, as we believe, only bad historical writing would attempt to ignore Luther's own understanding of justification, and if we attribute to Luther motivations which he did not accept but which were based on our Marxist assignment of him to a particular social class, then, by the same token, we would be writing bad Pentecostal history if we completely ignored the interpretation of historical events accepted by the participating Pentecostals.

My contention, therefore, is that it is impossible to write Pentecostal history without reference to providence, and that this is for two reasons: first, because providence figured largely in the thinking of the early Pentecostals and, second because providence is integral to church history generally. It seems to me to be axiomatic that any historical account must be recognisable by its original participants. This axiom, like all axioms, cannot be proved, but if it is rejected, we assume that the interpretation of primary sources (i.e. those sources provided 
by participants) may legitimately be alien to the providers of primary sources. But the disjunction between source and interpretation is unacceptable because every source is inevitably a mixture of fact and value, of data and theory, of information and interpretation. Thus the failure to preserve some connection between source and interpretation is essentially a distortion of the source.

All this may be clarified a little by an example. If we read a testimony of healing written in the 1930s there is likely to be an implied theology within the account. If we re-interpret the data to such an extent that it is unrecognisable by the person who has been healed, then it seems to me we have vitiated our source. Having said this, there is bound to be a certain amount of leeway for the interpretation of sources, and some sources may not only be inaccurate but also deliberately biased. All this is a matter for enquiry: my contention remains that Pentecostal history presumes the operation of providence.

The second point that church history in general presumes providence can be quickly established. Taking two well known early historians, Eusebius and Bede, one can easily find examples where they presumed providential action. Eusebius understood the fall of Jerusalem in AD 70 to be a judgement of God on the Jews (111.5), only held back by the presence of the apostles in the city until that date (111.7). Later the victory of Constantine is attributed directly to God's favour (X.8). In Bede we read of similar occurrences: the death of St Alban is witnessed by a crowd "who were doubtless moved by God's will to attend the death of his blessed confessor and martyr" (1.7). After the departure of the Romans from Britain, plagues and invasions begin. Britons called on the Saxons for help but "this decision, as its results were to show, seems to have been ordained by God as a punishment on their wickedness" (1.14).

\section{Biblical Models}

Clearly the Bible not only contains huge amounts of historical writing but also has a special relationship with the faith community of the church. For this reason my second contention is that the writing of Pentecostal history should have some resemblance to the historical writings of the Bible; the writings of the Bible should serve as a model for the writers of Pentecostal history - and indeed any Christian history writing. The other main alternatives, as we shall see later, are either to give precedence to the theories generated by secular historiography or to combine biblically based and secular historiography by a deliberate synthesis. This third "combination option", however, is really a variant of my contention.

If we grant that biblical history has a part to play in the formation of Pentecostal historiography, then we immediately run into various problems, not the least of which is that there are often two or more authoritative accounts of the same events. We have four Gospels, parallel accounts of historical events in Israel in the books of Chronicles and Kings and occasionally these overlap with the same events in the prophetic canon. In this way the deliverance of Jerusalem in the days of Hezekiah occurs three times ( 2 Kings 19; Isa 37; 2 Chron 32). By including more than one inspired and authoritative account of the same events, the Bible implies a message for the historian: there is more than one correct way of looking at events.

If we couple the deliberately synoptic approach of the Bible with the problem of identifying providential events, then we have a dual source of difficulty, though not necessarily a dual source of contradiction since the same events are not at one and the same time labelled as providential and non-providential. 
The method by which the Bible identifies providential events is usually by explicit statement: "immediately, because Herod did not give praise to God, an angel of the Lord struck him down, and he was eaten by worms and died" (Acts 12:23); or "Hezekiah trusted in the Lord...and the Lord was with him; and he was successful in whatever he undertook. He rebelled against the king of Assyria...he defeated the Philistines" (2 Kings 18:5-8). These statements usually appear at the end of an historical sequence and summarise either the judgement or the blessing of God on an individual. Such statements very often fit into a wider theological framework, but for the purpose of the modern Pentecostal historian it is important to notice that similar events can be evaluated differently by biblical writers. So, for example, while Herod's death is seen as richly merited and divinely caused, the death of James the brother of John (Acts 12:2) is unmerited and only explicable by the evil of those who inflicted it. At no time do the biblical writers hint that James was more evil than his longlived brother John, or indeed less deserving than Peter who escaped from the same wave of persecution. Nor, reverting to the Old Testament, do the writers of Kings and Chronicles give us a very full explanation for the death of Josiah. Here is a godly king who does everything right, yet he dies opposing Pharaoh, the archetypal villain. Admittedly Josiah's death is attributed to Manasseh's wickedness (2 Kings 23:26) and Josiah's goodness is seen in the fact that he does not witness the destruction of his beloved Jerusalem. For the modern historian, however, it is extremely difficult to make an authoritative comment on why some churches, some preachers and some people seem to escape harm and others have their lives cut short. What we need to guide us is a comprehensive and explicit doctrine of providence.

\section{Secular Models}

A study of the development of secular historiography shows it to have changed considerably since the days of Herodotus and Thucydides! Even the last 300 hundred years have seen changes. The original willingness of historians to see a pattern and purpose to history, often a pattern and purpose derived from sacred history of various kinds - usually Jewish or Christian - was replaced by an insistence on the objectivity of history or, to put it another way, by calling history "scientific". Even quite recently J.B. Bury (1861-1927) continued this positivist tradition of history writing by giving great, even obsessional, importance to fact gathering. At its simplest this idea presumed that by accumulating a mountain of facts, the truth of a situation or a revolution or a war or any historical event would be discovered. The problem with this approach, as Bury himself came to realise, was that facts in themselves are not a great deal of use unless they are connected to each other. E.H. Carr (1892-1982), who has written voluminously on Stalinist Russia, takes trouble to point out that facts only become historical facts in the hands of the historian. It is what the historian selects as salient which confers on a fact its importance. Hundreds of facts may be recorded - whether Shakespeare was right or left handed, whether Alexander the Great was a tall or a short man but these facts do not become significant until they are fitted into a sequence. Moreover, each data source that an historian may examine is itself a selection of facts from numerous other ones which might have been recorded. The diary of a politician or an old newspaper, even minutes of meetings and photographs, are selective. To say therefore that history is the accumulation of "neutral" or unselected and therefore unbiased facts, is absurd. To Carr, the historian must steer a middle course between "an untenable theory of history as an objective compilation of facts, of the unqualified primacy of fact over interpretations and the equally untenable theory of history as the subjective product of the mind of the historian" (1984, p. 29). 
The role of accident in history does preclude the possibility of determinism. There are no laws of history to discover, but he says, accidents may be expected to cancel each other out over long periods of time so that whereas some battles are accidentally lost others are accidentally won. General explanations of events can therefore be offered without embracing simple-minded determinism.

This brief discussion of problems within secular history is simply intended to show that, even if Pentecostal and church history were to make unrestricted use of the models and methodologies of secular history, there would be crucial choices to make because, as I have contended above, Pentecostal and church history must invoke the concept of providence and secular historiography is bound to deny this on the grounds that large scale theories of the divinely ordained purpose and destiny of the human race are ruled out of court.

There is also one other problem in the utilisation of secular theories and models in Pentecostal history and this concerns the incorporation of sociological theories within an overall historical framework. Again an example will make this clearer. Recent studies of the Old Testament have made extensive use of sociological theories to explain the emergence of the Israelite state, the conquest of the land or the place of the prophets in Israelite society. All these explanations apply insights based on different and more modem cultures to Israelite culture: if aboriginal or Inca tribes have certain values and exhibit certain dynamics, then these are judged to be applicable to ancient Israel. The point at issue, of course, is that there is simply no proper way of testing such transferences from one culture to another or from one historical epoch to another. We do not know whether Israelite culture, for example, experienced a peasant revolution in or around the time of Joshua. Now, while no scholar would want to rule out the use of all sorts of methods to make sense of history, it should also be apparent that the use of what is effectively historical sociology is capable of misleading representations of events. My immediate point, however, is simply that there are distinct difficulties in the use of sociology as an aid to history or as a sub-section of it.

\section{Three Generations On}

Because the Pentecostal movement is about 100 years old, there is no one alive today who can remember the earliest meetings and discussions held by the first generation of Pentecostals. It is even difficult to gain impressions from men and women who can remember the 1920s with any clarity. Of itself this is not overwhelmingly important to a historian, except insofar as there may be questions which the historian wishes to put to his documentary data to which he can gain no answer. Again an example may help to explain this point. In a recent history of British Assemblies of God, I was at one stage interested to discover how frequently the congregation were invited to participate in the meetings and what the "flavour" of these meetings was. Were the chairs arranged in rows or in a circle? Did the pastor invite testimonies often or rarely? How many people, compared with those who were prayed for, were actually healed? What sort of attitude did other Christians have to Pentecostals in the 1920s? Which music and songbooks were regularly used in the meetings? Was everyone expected to attend all the meetings and how many of these were there each week? Were people prayed for their baptism in the Spirit at the front of the meeting or in the vestry? Answers to these and similar questions can only be inferred from the literature. An interview with a veteran can cast considerable light on the rhythm and pattern of church life and answer such questions more directly. Where the literature does not help us, the recollections of the elderly can begin to help us deduce what is meant by a "large meeting". Where magazines or tracts are full of testimonies of healing, we can learn about less publicised people who did not get healed. Where we are attempting to trace an influence between Pentecostals and their 
antecedents, we are in a stronger position to make deductions if we know whether the pattern of meetings resembled that of the Salvation Army or the Methodists, and if the songs were taken from these sources as well.

The problems posed by the distance of the Pentecostal movement from its origins are the other side of this coin. Whereas there is much the elderly can tell us and whereas they can recall impressions and conflicts unrecorded by the documentary evidence, their memories are fallible and often tantalisingly imprecise. If you ask an old man, "Did this evangelistic campaign happen before or after 1930?" the answer is a shrug of the shoulders. And the same may apply to numbers of all kinds: how big was this church, how much was paid for this building, how old was that preacher? If you try to find out details of a scandal, the old person often knows less of it than the historian because the scandal was concealed from contemporaries. In general, of course, those with most to tell are those who were at the centre of the action. The Executive Presbyter, the founder of a missionary society, the evangelist and the pastor often have the most rewarding memories for the historian and the main difficulty the historian faces is in trying to prise the facts from the elderly leader before his memory fails or he goes to his grave.

\section{THEOLOGICAL AND PHILOSOPHICAL PERSPECTIVES}

\section{Providence}

Wacker (1988) in an illuminating discussion points out the original Pentecostal view of history was that it was linear (not cyclical) and that Pentecostals had been divinely raised up within a calendar of events determined by God for particular purposes with regard to the church and to the whole world.

He goes on, "A more serious deficiency in the work of the early historians was their lack of critical standards. By this I mean that they were unable or unwilling to see sound historical writing consisted of the presentation of publicly available facts and the interpretation of those facts in terms of publicly available theories of human motivation and social change. ..theological assertions smuggled in as historical 'facts' violated the rules by which the game was supposed to be played".

This quotation does not deny divine providence, rather it suggests that early Pentecostal historians were partial and worked to a hidden agenda, perhaps intended to maximise the importance or doctrinal originality of a specific personality, or perhaps intended to give the Pentecostal testimony greater credibility. The problem Wacker highlights is that of pretending that certain theological statements can be turned into historical facts. To say, for example, "The fact that God raised up the Pentecostal movement in these last days..." is an instance of what is meant.

No serious modern Pentecostal historian would confuse theology and history in quite this way and it is only likely that statements of the kind given above would be made after considerable argumentation and the giving of evidence. What I am suggesting the modern Pentecostal historian would want to do is to make an application of the principles outlined in 1 Corinthians 12 and 14 with regard to the judgement of prophecy. Paul's issuing of those guidelines immediately indicates that New Testament prophecy was fallible and subject to correction. A prophet might think that he had the mind of the Lord on a matter and then have to be corrected by his peers. This tentativeness seems an appropriate stance for the 
Pentecostal historian, particularly if the biblical model of historiography is taken seriously. Statements about divine providence can therefore be made, but they are acknowledged as being fallible and open to correction.

An interesting and complex example of the kind of problem which can face the Pentecostal historian occurred in British Assemblies of God when in the late 1960s John Phillips, then a member of the Executive Council, gave a prophecy to the ministerial Conference which had the effect of suspending its business sessions for three years. Not only did the other members of the Executive Council at that time, and indeed the Conference as a whole, have to adjudicate the matter but the historian writing later is also drawn into an assessment of the prophecy.

Was it a divinely inspired, and consequently providential, utterance? Was it to be explained as a psychological aberration? Or should the utterance have been seen as a false prophecy - a kind of anti-providential event? If the historian refuses to commit him or herself on the matter, or at the very least refuses to recognise the issues raised, we are surely entitled to doubt his or her appreciation of the significance of the phenomenon. But what we have here and this is why the issue is complex - is an historical judgement on a theological judgement.

Ward (1990) in a strictly philosophical defence of divine providence points out the inherent difficulties in detecting providential acts. Not only are those who reject God unable to discern providence, but also those who accept God may only discern his dealings with them imperfectly and understand his intentions inadequately. Human beings are finite and capable of self-deception and they live in a structured world where the regularities of nature and of cause and effect may actually inhibit the freedom of God to protect all individuals from harm all the time. Ward pictures three people in relationship with one another: A is domineering and greedy, B is self-deceptive and manipulative and $\mathrm{C}$ is weak and spiteful. Providential acts can hardly occur to eradicate these various personal faults. Blessing A materially makes him worse in both his vices, not blessing him materially also has the same effect. And Ward works the example through to show how, if the aim of providence is to reveal divine selfgiving love, this is problematic because $\mathrm{A}, \mathrm{B}$ and $\mathrm{C}$ interact with each other along the lines set by their vices and this leads them consistently to miss the point.

For the purposes of this paper, Ward's comments show two things: (i) how an up to date and sophisticated philosophical defence of divine providence may be given now that the universe is seen as open rather than mechanistically closed and (ii) why providence is in principle difficult to discern.

\section{Biblical Models}

The opening verses of Luke's Gospel self-consciously show the writer's method of working. He made enquiries of a tradition which stemmed back to eyewitnesses and he set the results of his enquiries in order. This method, which the Church has recognised as producing a canonical document, is interesting for the light it throws on appropriate historical methods. The role of oral tradition is clearly attested by Luke (though written sources are also referred to), but he deems it appropriate to investigate tradition and then to set the results of his findings down in a written form. This set of factors - tradition, eyewitnesses, written sources, investigation - come together in the present time and can be used with regard to Pentecostal history. 


\section{THE IMPLICATIONS}

\section{A Time to Write}

Now is the time to write. The existence of a reasonably well established tradition, the extensive but manageable quantity of documentary sources, the testimony of a few elderly eyewitnesses, the self-consciousness about historiography, the interest in the past evinced by the third generation of Pentecostals or the second generation of charismatics, the general ease of travel and the classification of archival materials all added together make this a time to write Pentecostal history. No doubt, if another 100 years pass, a revisionist phase will begin and the history books will be re-written from different perspectives and by different theorists. But at the moment this is our opportunity to write in the pursuit of truth and for the sake of the present generation.

\section{A Time to Examine Historiographical Models}

As I have tried to show, there are both biblical and secular models of historiography, and these will result in different kinds of accounts of Pentecostalism. If I had not contended that providence was crucial to the writing of church history generally and Pentecostal history in particular, I should have been happy to agree that contradictory accounts of the same events could all stand and be of equal value and that there is ultimately no such thing as historical truth. But it is not only an unwillingness to admit this sort of relativism on philosophical grounds, it is also an unwillingness to admit it on the grounds I have described earlier which leads me to argue that, although there will be diverse accounts of Pentecostal events, I would expect an overall cohesion between them. In other words my acceptance of providence also leads me to expect some sort of cohesiveness between historical accounts of the Pentecostal movement, even if those accounts stem from different intellectual frameworks.

As a preliminary requirement for this expectation, I would suggest the careful examination of historiographical models is necessary. To the extent that any methodology presumes certain conclusions, it is important that the users of secular historiographical methods are aware of the violence they may do to the data of Pentecostal history. Again, an example will help: any secular account of Pentecostals which attempts to explain glossolalia entirely in psychological terms as "psychobabble", "vocalisations from the unconscious", "a learned behaviour" etc., has to be extremely careful to spell out the evidence for these assertions and to look at the counter evidence. If this is not done, we end up with a form of Pentecostal history which has been simply translated into secular terms along the following lines: "A large number of people underwent psychological excitement in Azusa Street and thought themselves filled with the Holy Ghost to such an extent that the normal racial barriers between black and white were broken down by emotions popularly designated as love but which we know to be caused by changes in the autonomic nervous system". In my judgement such a translation becomes a travesty.

\section{SOLUTIONS TO THE PROBLEMS OF PENTECOSTAL HISTORY}

1. A common solution to the problems of Pentecostal history, that is, to the large number of reported miracles (or providential occurrences) is to ignore most accounts of healing etc. or to mention miracles primarily in their theological context. Any reference to the baptism in the 
Spirit or to healings are then reported by the historian as being part of the doctrinal development of the Pentecostal church. The question of the truth of the experience on which the doctrine is based, indeed the questions which arise about the correct relationship between doctrine and experience, and the way doctrinal statements can be tested, are usually ignored. What tends to happen in this sort of Pentecostal history is that miracles are reported by the historian if they are confirmed by secular sources like newspapers.

After selectively including miracles for which there is some (secular) evidence, the historian may feel able to generalise about the significance of the Pentecostal movement as a whole on the basis of its miraculous content.

Now, I do not want to pour scorn on this way of writing history. Very often the earliest Pentecostal historians were Pentecostal by experience and accepted the theoretical intrusion of providential events. It obviously makes sense to examine accounts of miracles in the secular media. Donald Gee does this sort of thing in his The Pentecostal Movement: "some notable miracles are reported to have taken place" (p. 47). Or as an example of a miracle set in its theological context, "the power of God fell very quietly upon one of their company, and he was baptised in the Holy Ghost and spoke with tongues" (p. 71). As an example of the use of summarising statements we have, "The amazing freedom of the meetings gave opportunity for undesirables to take advantage for personal ends. Definitely false teaching was more easily dealt with. Through it all God preserved the work" (p. 63/64).

In essence, then, we can investigate the workings of providence in a previous era (i) by giving particular weight to secular or hostile reports of miracles and (ii) by assuming that miracles took place to establish widely accepted doctrines.

While this sort of treatment of Pentecostal history is simple and readable, it suffers from various defects: (i) no explicit criteria are given for accepting some miracles and rejecting or not reporting others; (ii) there is very often little discussion of the interaction between doctrine and experience; (iii) the summarising statements may or may not be correct, but they are very obviously less well related to verifiable events than reports of individual miracles; (iv) there may be confusion between the judgment of the historian and verbatim reportage by participants in historical events.

2. A second solution is to minimise miracles by constantly and consciously referring to the interpretation of historical events given by participants. Thu this point people spoke in languages they believed to be New Testament glossolalia and so they thought themselves filled with the Holy Spirit". This style of history writing can blend in well with a description of the sociological contours of a movement. Miracles are not denied, but they are left, as it were, in brackets without any real comment from the historian.

This sort of history operates at two levels. We are told what the participants in events thought and said, but we maintain a distance from them. The historian can speak with the benefit of hindsight and perhaps with a greater understanding of the overall context of events. At the first level, therefore, we hear about events through the mouths of participants. At the second level we read of the connection between events and learn of their significance through the words of the historian. At the first level we may find an event described as miraculous; at the second level the same event may or may not be considered explicable by other factors. But a good historian ought to come out from behind the curtains and explain just where he or she stands on the matter of miracles. The problem of Pentecostal history is then solved by a consistent application of the historian's criteria to reports of providential events.

Sociological investigations of Pentecostalism can help here. Poloma $(1985,1989)$ gives an example of a questionnaire on healing in sixteen Assemblies of God congregations. She lists 
the questions which were asked, the percentage of answers given to each predetermined category and the correlations between the replies. She was able to show, for example, that over half of her respondents $(61 \%)$ claimed to have received healing, and over half of these (5 1\%) had received their healing in a worship service. There was no statistical correlation between experience of healing and either age or sex.

The historical use of such hard data is twofold. First, it will be important for historians of the future. If similar questions are asked of similar congregations at twenty year intervals, we should have accurate measurements of the prevalence of miracles, congregational perceptions of the role of healing and a variety of other matters relevant to our understanding of a particular stage of denominational development. Second, the data may be extrapolated backwards to give us an indication of the kinds of figures we might reasonably have expected in the past. So, if Poloma's figures show us that in 1983, when the data were collected, that over $60 \%$ of people in Assemblies of God congregations claimed to have experienced healing, we might be justified in assuming that the figure was similar in 1963 and, by this means, fill out our description and comprehension of that period.

There is an interesting and important parallel here. Just as we can cautiously extrapolate data backwards in order to comment on a past era, so we can do the same thing, in commenting on moral matters. All church history contains both moral triumphs and moral lapses. Some historians take the view that it is important in the interests of objectivity to avoid any comment on the morals of the past. Others feel they must comment on the failures and oddities of the past and they inevitably do so from the perspectives of the present (see Chadwick, 1987). But there is a genuine dilemma here. If historians ignore the lapses of the past, they seem to be amoral themselves; if they make moral judgements on the past, they stand accused of applying inappropriate criteria to societies whose moral norms were different from our own. If we grant the legitimacy of the historian's moral perspective - and as a Christian I would find it very difficult to suppress the moral dimension in human conduct - then what we do in the moral sphere is similar to what we may do in the statistical sphere. We take measurements from the present and cautiously apply them to the past. I recognise that in accepting numerical data and the legitimacy of extrapolations into the past, I may appear to be contradicting what I said earlier about the application of anthropology to the Old Testament, but the difference in this instance is that, whereas anthropological data are being applied to a society which existed 3000 years ago, I am only urging applications of data over a period of about 50 years; it is the time scale rather than the principle which is different.

Further use of questionnaire techniques - particularly multiple regression analysis - could bring precision to the whole area of healing and miracles. We could discover not only how many people were healed, but what sort of complaints they were healed from, their general world view, the medical diagnoses given to their conditions both before and after prayer, and so on. In addition the historian could make use of a phenomenological approach to the data. This approach, based on the philosophy of Edmund Husserl (1859-1938), has been extensively adopted with anthropological studies of religion. The idea, in brief, is to enter uncritically into the world-view and experience of the respondent and then to describe the experience. Both Husserl's philosophy and the studies of religion which stem from it are open to serious criticisms (Kay 1983), but it remains true that only recently are historical studies of Pentecostalism attempting to present, as it were from the inside, the sub-culture of early Pentecostalism. Blumhofer's recent two volume history of American Assemblies of God takes a step in this direction, particularly by reference to the music and eschatology of the average early Pentecostal. The historian, in other words, embraces the subjective view of his or her sources of data: this is how it seemed to them then, this is how they felt, and 
thought and why they acted as they did. They are not peculiar people because their worldview has an internal logic of its own.

In essence, then, we can investigate the workings of providence in our own era and use these findings to illuminate the past.

\section{RECENT EXAMPLES OF HISTORY WRITING}

Finally, I thought it would be helpful to give examples from three modern books on Pentecostal history to illustrate that the problems and answers do run along the lines outlined above.

Take, for example, this account of Parham's early ministry by Blumhofer (1989). "In Parham's personal religious world, events and decisions were charged with spiritual significance. When his frail health deteriorated, he concluded that God was punishing him...afflicted with continued weakness in his ankles, Parham 'brought forcible arguments in prayer', soliciting full recovery. Instantly restored, Parham claimed a 'revelation' that education would be detrimental to effective ministry, left school..." (p. 70). Blumhofer distances herself from Parham's interpretation of events without denying it completely. She talks of his "personal religious world", his conclusion that God was punishing him and his "revelation" where the inverted commas let the reader know that the word is Parham' $\mathrm{s}$ and not Blumhofer's. This style of writing about Pentecostal events verges on the second of the two solutions.

Or, take Gary McGee (1986) describing the Azusa street meetings and delineating the beliefs of the participants, "The Azusa Street participants, in the pattern of Parham and his students, believed they were living in the last days...to them, the fulfilment of Joel's prophecy gave global evangelism an additional thrust. ..Seymour and his associates believed with Parham that the languages spoken by the power of the Holy Spirit were meant to be used in missions" (vol 1, p 44). These statements are substantiated by appropriate quotations from primary sources. Here, then, the author neither agrees nor disagrees with the opinions he is describing - he is commendably attempting only to explain and recreate the events under his consideration.

But another example shows how authorial constructions can be placed upon events on the assumption that the interpretations of participants are correct. Thus under the heading "Providential Happenings", McGee describes the wealth of documentary evidence for signs and wonders and then takes recent revival-style occurrences in Argentina (which were sparked off by defeat in the Falklands War) as having occurred providentially - out of evil good came (vol 2, p. 271). Here the author, by using a summarising heading, veers towards the first solution given above.

Finally, take C W Conn's Like A Mighty Army (1977). In the early chapters he tells us, "The emotion that made the worshippers weep, laugh, and shout was not some indefinable psychological delirium; it stemmed from the exaltation they received from a sense of the presence of God" (p. 23). Conn, therefore, deliberately rules out psychological explanations of certain phenomena. Earlier he says of Spurling's ministry, "without fully realising how momentous was the occasion, yet thoroughly recognising the divine urgings within him..." (p. 7) and "what kept the lone figure encouraged and undaunted can be explained only as the inspiration of the Spirit" ( $\mathrm{p}$ 14). Conn, then, is quite prepared to attribute the work of the Holy Spirit both to the lives of individual preachers and to larger gatherings, even when this 
evidence only comes from deductions based on primary sources rather than primary sources themselves. Here the author, on the basis presumably of his own religious experience, interprets earlier events. In this sense, Conn veers towards the second solution, but my preference would be for a greater explicitness in explaining how the work of the Holy Spirit was detected.

These quotations do not, perhaps, do justice to the complexity of the historian's interaction with, and identification of, providential events, because the historian can adopt both the solutions given above in the same piece of writing but they do, I hope, show that the issue is alive and important one. It is certainly one I have wrestled with in writing a recent history of British Assemblies of God.

\section{BIBLIOGRAPHY}

E.L. Blumhofer, The Assemblies of God: A Chapter in the Story of American Pentecostalism, 2 vols. (Springfield: Gospel Publishing House, 1989).

E.H. Carr, What is History? (Harmondsworth: Penguin, 1964).

O. Chadwick, “Acton and Butterfield”, Journal of Ecclesiastical History 38 (1987).

C.W. Conn, Like a Mighty Army: A History of the Church of God, (Tennessee: Pathway Press, 1977).

W.K. Kay, "RE and Phenomenology" in Bulletin for Association of Religious Education $15.41(1983)$.

G.B. McGee, This Gospel Shall Be Preached 2 vols. (Springfield: Gospel Publishing House, 1986-1989).

M.M. Poloma, "An Empirical Study of Perceptions of Healing Among Assemblies of God Members" Pneuma 7.1(1985).

M.M. Poloma and B.F. Pendleton, "Religious Experiences, Evangelism, and

Institutional Growth within the Assemblies of God" Journal for the Scientific Study of Religion 28.4 (1989).

G. Wacker, (1988), "Biography and Historiography of Pentecostalism (US)" Dictionary of Pentecostal and Charismatic Movements, Stanley M. Burgess and Gary B. McGee, Patrick H. Alexander, eds. (Grand Rapids, MI: Zondervan, 1988).

K. Ward, Divine Action (London: Collins, 1990). 